研究課題別研究評価

1. 研究課題名 : 軟体動物の特異な遺伝現象に関する基礎的研究

2. 研究者名: 上島 励

3. 研究の狙い:

後生動物のミトコンドリア DNA(mtDNA)は約 16kbp の環状ゲノムで、37 種類の遺伝子をコ一ドしている。 後生動物の mtDNA ゲノム構造は保守性が高く、ゲノム上の遺伝子の配置は動物門を超えて保存されて いることが知られている。しかし、軟体動物 (特に、腹足類) は例外で、mtDNA のゲノム構造が大きく変化 していることが研究者らによって発見された。ゲノム構造の多様性が高い軟体動物は、mtDNA ゲノムの 分子進化を研究する絶好のモデルといえる。本研究では、1)軟体動物の mtDNA ゲノム構造が、どのよ うにして多様化したのか、その分子進化過程を明らかにし、2)ゲノム構造の変異性がなぜ一部の動物群 だけで高くなるのか、その要因を解明することを目指した。

4. 研究結果および自己評価:

腹足類の主要な高次分類群全てについて、mtDNA の全ゲノム構造または部分的構造を決定し、ゲノ ム構造の変異性を明らかにした。また、分岐分類学的な解析を行い、腹足類の遺伝子配置は、最も原 始的な特徵を残す「古腹足類型」から、「新生腹足類型」、「ミズシタダミ」の中間段階を経て、最後に「高 等異鰓類」が進化したことを示した。腹足類におけるゲノム構造の大規模な再配置は、コ一ドされている 遺伝子の逆位や転座が徐々に蓄積することによって、段階的に生じたと考えられる。この mtDNA 遺伝子 配置の分子進化過程は、形態学的特徵から推定された腹足類の系統分岐パターンと合致し、ゲノム構 造の変化が系統解析の有効な分子マーカ一であることを裏付けた。

次に、化石記録と系統関係からゲノム構造の進化速度を推定した。腹足類の mtDNA ゲノム構造は約 5 億年に渡ってほとんど変化しない分類群がある一方で、約 5 千万年の間に急激に再配置が起こる場合 もあり、ゲノム構造には分子時計が全く成立しないことを示した。これは、ゲノム構造の経時的進化過程 を示した初めての例である。

さらに、2 種のクルマガイ類について mtDNA の全ゲノム構造を決定し、クルマガイ類の mtDNA は腹足 類の中で最も特殊化したゲノム構造をしていること、および遺伝子配置の変化速度が著しく速くなってい ることを発見した。クルマガイ類を含めて、遺伝子配置が大きく変化している腹足類のゲノム構造、塩基 組成等を詳細に比較したところ、遺伝子配置の変化速度と関連している特徵を発見し、ゲノム複製時の fidelity の低下およびゲノムサイズの縮小化に伴うプロモータ一領域の消失がゲノム構造の再配置を促 進する重要な要因であるという仮説を提唱した。このモデルは他の分類群のデータとも整合し、オルガネ ラゲノム進化の一般的なモデルになると期待される。

mtDNA ゲノム構造の多様性と進化過程を明らかにするという当初の目的は、腹足類についてはほぼ 達成されたので、今後は、この仮説の妥当性を証明するために、DNA polymerase の fidelity を直接比較 すると共に、ゲノム構造の変化速度が著しく速くなっているクルマガイ類等について近縁種を中心にさら に多くのデータを集め、また核ゲノム構造との関連についても検討を行いたいと考えている。

二枚貝類についても、いくつかの分類群について mtDNAゲノム構造解析を行った。二枚貝類では同属 別種の間で、遺伝子配置のみならず遺伝子組成も大きく変化する場合があり、ゲノム構造の多様性は 腹足類をはるかに凌駕することを発見した。今後は二枚貝類については、さらに多くのデータを集め、ゲ ノム進化の詳細な解析を行う予定である。なお、原始的な分類群では祖先的な遺伝子配置が残っており、 遺伝子配置の変化速度の遅い分類群では塩基置換速度も遅いなど、腹足類から推定されたモデルと合 致するデータも得られており、上記の仮説を支持するデータが得られるものと期待している。 


\section{5. 領域総括の見解：}

軟体動物の形態学と遺伝子配列決定法を習得した後、軟体動物のミトコンドリア DNA 配列パターンが 他の生物に比して大きく変化しており、それが系統進化とともに起こっていることを明らかにした点で、ま ことにユニークである。生物進化から見ても有意義な発見といえる。より効果的な発表方法 - 専門誌 だけでなくもっと一般に知られる科学誌への投稿 一 を心がけてほしい。

\section{6. 主な論文等:}

(1)S. Yokobori, T. Ueda, G. Heldmaier-Fuchs, S. Paabo, R. Ueshima, A. Kondow, K. Nishikawa and K. Watanabe (1999). Complete DNA sequence of the mitochondrial genome of the acidian Halocynthis roretzi (Chordata, Urochordata). Genetics 153:1851-1862.

(2)A. Kurabayashi and R. Ueshima (2000) Complete sequence of the Mitochondrial DNA of the Primitive Opisthobranch gastropod Pupa strigosa: Systematic Implication of the Genome Organization. Mol. Biol. Evol.17(2):266-277.

(3)A. Kurabayashi and R. Ueshima (2000). Partial mitochondrial genome organization of the heterostrophan gastropod Omalogyra atomus. and its systematic significance. Venus 59(2): 7-18.

(4)Y. Noguchi, K. Endo, F. Tajima and R. Ueshima (2000) The mitochondrial genome of the branchiopod Laques rubellus. Genetics 155: 245-259.

(5)Y. Shimizu and R. Ueshima (2000) Historical biogeography and interspecific mtDNA introgression in Euhadra peliomphala (the Japanese land snails). Heredity 85: 84-96

(6)稲葉明彦,上島励 (1999), 軟体動物研究法. 軟体動物学入門(下巻), 波部忠重, 奥谷喬司, 西脇三 郎共編. サイエンテイスト社

(7)奥谷喬司,太田秀,上島励編 (1999) 水産無脊椎動物の最新学 東海大出版会

(8)上島励 (2000) 動物系統分類学の新展開-分子系統学の現在と未来-. 動物系統分類学、追補版:113. 中山書店

（9)中山剛,上島励 (2000) 単細胞生物から多細胞生物への進化. 遺伝,別冊 12:134-154

(10)上島励 (2000) 軟体動物. 生物の種多様性 5 巻 無脊椎動物の多様性と系統（節足動物を除く） 169-192 . 裳華房

\section{国際会議招待講演}

Rei Ueshima; Extensive mitochondrial genomic rearrangement and gastropodan phylogeny, International Symposium on Biodiversity. Nara,3-5 Dec.1999

外部発表 27 件(論文 5 件、総説、解説等 5 件、口答発表: 国際会議2件、国内会議 15 件) 